\title{
Profile of children diagnosed with autistic spectrum disorder managed at a tertiary child development unit
}

Lian WB, Ho S

Singapore Med J 2012; 53(12): 794-800

The citation of this article should be Singapore Med J 2012; 53(12):794-799. The correct reference list should be:

\section{REFERENCES}

1. Childhood Developmental and Behavioural Disorders (CDABD) Database, SingHealth Cluster Research Funding 2003-5.

2. Lian WB, Ho S, Choo S, et al. Children with developmental and behavioural concerns in Singapore. Singapore Med J 2012; 53:439-445.

3. Kohler L, Jakobsson G. Clinics in Developmental Medicine. In: Children's Health and Well-Being in the Nordic Countries. Oxford: MacKeith Press, 1987: 98.

4. Autism and Developmental Disabilities Monitoring Network Surveillance Year 2006 Principal Investigators; Centers for Disease Control and Prevention (CDC). Prevalence of autism spectrum disorders - Autism and Developmental Disabilities Monitoring Network, United States, 2006. MMWR Surveill Summ 2009; 58:1-20.

5. Williams E, Thomas K, Sidebotham H, Emond A. Prevalence and characteristics of autistic spectrum disorders in the ALSPAC cohort. Dev Med Child Neurol 2008; 50:672-7.

6. Boyle CA, Decouflé P, Yeargin-Allsopp M. Prevalence and health impact of developmental disabilities in US children. Pediatrics 1994; 93:399-403.

7. Denver Developmental Screening Test. Singapore, 1992.

8. American Psychiatric Association. Diagnostic and statistical manual of mental disorders (4th ed text revision); Washington DC: American Psychiatric Association, 2000.

9. Wing L, Gould J. Severe impairments of social interaction and associated abnormalities in children: epidemiology and classification. J Autism Dev Disord 1979; 9:11-29.

10. Xu LM, Li JR, Huang Y, et al. AutismKB: an evidence-based knowledgebase of autism genetics. Nucleic Acids Res 2012; 40(Database issue): D1016-22.

11. Rhoades RA, Scarpa A, Sailey B. The importance of physician knowledge of autism spectrum disorder: results of a parent survey. BMC Pediatr 2007; 7:37.

12. Lord C, Rutter M, DiLavore PC, Risi S. ADOS. Autism diagnostic observation schedule. Los Angeles: Western Psychological Services, 1999.
13. Gotham K, Pickles A, Lord C. Standardizing ADOS scores for a measure of severity in autism spectrum disorders. J Autism Dev Disord 2009; 39:693-705.

14. Kanner L. Autistic disturbances of affective contact. Nerv Child 1943; 2:217-50.

15. Kanner L. [Follow-up study of eleven autistic children originally reported in 1943. 1971] Psychiatr Enfant 1995; 38:421-61. French.

16. Laidler JR. The 'Refrigerator Mother" Hypothesis of Autism. Autism Watch 2004 [online]. Available at: www.autism-watch.org/causes/rm.shtml. Accessed May 11, 2012

17. Bettleheim B. The Empty Fortress: Infantile Autism and the Birth of the Self. New York: The Free Press, 1967.

18. Rimland B. Infantile autism: the syndrome and its implications for a neural theory of behavior. New York: Appleton-Century-Crofts, 1964: p282.

19. Muhle R, Trentacoste SV, Rapin I. The genetics of autism. Pediatrics 2004; 113: e472-86

20. Russell G, Steer C, Golding J. Social and demographic factors that influence the diagnosis of autistic spectrum disorders. Soc Psychiatry Psychiatr Epidemiol 2011; 46:1283-93.

21. Renty J, Roeyers H. Satisfaction with formal support and education for children with autism spectrum disorder: the voices of the parents. Child Care Health Dev 2006; 32:371-85.

22. Williams E, Thomas K, Sidebotham H, Emond A. Prevalence and characteristics of autistic spectrum disorders in the ALSPAC cohort. Dev Med Child Neurol 2008; 50:672-7.

23. Rutter M, Le Couteur A, Lord C. ADI-R. Autism diagnostic interview revised. Los Angeles: Western Psychological Services, 2003.

24. de Bildt A, Oosterling IJ, van Lang ND, et al. Standardized ADOS scores: measuring severity of autism spectrum disorders in a Dutch sample. J Autism Dev Disord 2011; 41:311-9. 